\title{
OPEN ELECTRONIC RESOURCES ON THE INTERNET AND THE FORMATION OF INFORMATION COMPETENCIES AMONG STUDENTS IN HIGHER EDUCATION
}

\author{
Alexander Vlad. Grigoriev ${ }^{1}$, Mikhail Kharitonov ${ }^{2 *}$, Sergey Kodybaykin ${ }^{3}$, Svetlana \\ Selivanova ${ }^{4}$, Irina Muravyeva ${ }^{5}$, Alexander Dm. Grigoriev ${ }^{6}$ \\ ${ }^{1}$ Assoc. Prof. Dr., Chuvash State University, RUSSIA, gavpost@mail.ru \\ ${ }^{2}$ Assoc. Prof. Dr., Chuvash State University, RUSSIA, muha21@mail.ru \\ ${ }^{3}$ Assoc. Prof. Dr., Chuvash State University, RUSSIA, skodyb@mail.ru \\ ${ }^{4}$ Assoc. Prof. Dr., Chuvash State University, RUSSIA, sveselivanova@yandex.ru \\ ${ }^{5}$ Assoc. Prof. Dr., Chuvash State University, RUSSIA, irina17-04@bk.ru \\ ${ }^{6}$ Assoc. Prof. Dr., Chuvash State University, RUSSIA, pu-900pis@yandex.ru \\ ${ }^{*}$ Corresponding Author
}

\begin{abstract}
Currently, many world universities are trying to intensify and complicate the learning process, to enrich the educational environment. This is achieved by various methods: electronic textbooks and lecture courses from electronic libraries are used; teachers and students are connected in social networks and on specialized educational platforms (Moodle and others); tasks are performed on the basis of publications from the Internet. These activities allow to form skills at a higher level, both for educational and professional tasks: critical assessment of the content of information; the ability to isolate the main; to form a structure in information flows; apply data in accordance with the tasks to be solved; other (Korableva E.V., Muzychenko M.Ya., 2018, p. 27). The article discusses the results of an experiment to check the level of formation of some informational and related competencies among students. The second-year students were tested for the following skills: to determine the purpose of the educational task; offer the best source for its implementation; develop an algorithm for completing this task; to do practically work according to the model. The research was carried out in line with a new direction in pedagogical science - the concept of «Pedagogical Competenceology» (Grigoriev A.V., 2019).
\end{abstract}

Keywords: Pedagogical Competenceology, Information competencies, Information skills, Level of competence formation, Open electronic resources, Students in higher education.

\section{INTRODUCTION}

In many universities still have problems associated with the transition to new methods of organizing the educational process, but with traditional content. The researchers note: «in higher education, there is a situation where the activity of students is replaced by the activity of the teacher. The leading activity remains for the teacher not only in lectures, but also in seminars, practical and laboratory classes. As can be seen from the observation of the educational process, almost $80 \%$ of practical classes are dominated by the teacher's monologue, as well as the control of the theoretical part of the course. Almost no attention is paid to the 
independent work of students» (Goncharova Ya. S. and etc., 2017, p. 77-78).

\section{METHODS}

The Writing of this article was preceded by an experiment, the purpose of which was to find out the level of formation of some educational competencies of students, mainly information. The method of analysis was used in the processing of pedagogical tasks performed by students. When students perform the second part of the work, the method of work by analogy was used. The interview was used for students' interpretation of the results of their work. The method of generalization was used in the work of the authors of the article on the conclusions based on the results of the experiment.

\section{RESULTS}

In the 2018-2019 academic year, in the second year of the faculty of history and geography of the Chuvash State University named after I. N. Ulyanov, the authors of this article conducted an experiment to determine the level of formation of a number of information competencies of students and, at the same time, to consolidate some skills. In the experiment, which took place within the framework of teaching the discipline «Business Communications», 97 students of seven training areas took part: «History» - 12 people; "Geography» - 14 people; «Ecology» - 20 people; «Documentary Science» - 11 people; «Tourism» - 21 people; «Land Management» - 9 people; «Applied Informatics» - 10 people. For the convenience of presenting data in tables, we will indicate the areas of training with numbers: «History» - 1; «Geography» - 2; «Ecology» - 3; «Documentary Science» - 4; «Tourism» - 5; «Land Management» - 6; «Applied Informatics» - 7.

The organizers of the experiment formulated the goal of the work as follows: «Learn to work independently with information and formalize the results of work in accordance with the presented sample, by analogy». All the work was carried out in two stages: first, students completed the first three tasks and the results of their work were discussed; at the second stage, they had to perform practical work - create an information table. The result of the first, theoretical stage of the experiment, was the development of recommendations for completing the task of the second stage. That is, before the second stage of the experiment, students already got a complete idea of how to approach the work with the search for information and compiling a table.

Students had to perform a comprehensive work: 1) independently determine the purpose of the proposed training task; 2) determine the optimal source of information for the task; 3) develop an algorithm for performing the proposed task; 4) perform the work according to the sample. First of all, students were asked to familiarize themselves with the sample work and were warned that they would have to perform similar work, but on a different empirical material. After reviewing the material, they had to complete the first three tasks by sending the written work to the teacher by e-mail.

Goal-setting as a skill is a necessary attribute in both educational and professional activities. The ability to formulate the goal of one's own activity greatly facilitates the fulfillment of training work and labor assignment, allows you to develop the necessary tasks as a tactic for achieving a strategic plan. Awareness of the goal not only makes it possible to consciously carry out educational and labor actions, but also acts as a motivator of activity, gives an emotional charge. It is precisely the psychological component in the content of this concept that the researcher from the Mordovian Republic of the Russian Federation E.A. Lezhneva (Lezhneva E. A., 2016, p. 86) draws attention.

A.M. Sergeeva claims that the formation: «there is a process of interpenetration of the student's goals - as needs that ensure his life in the future, with the goals - the teacher's tasks, solved «now» " (Sergeeva A.M., 2017 , p. 86). The author draws attention not only to the methodological aspects of the question, but also to the psychological side of goal-setting as a means of creating a psychologically comfortable atmosphere for students of study work (Sergeeva A.M., 2017, p. 86-87). Scientists also establish a link between motivation to study and students' acceptance of learning goals (Koreneva A.A., 2016).

The performance of the first task was evaluated according to a dichotomous scheme: the student completed or did not complete the task. Only 18 people or $18.6 \%$ were able to independently determine the purpose of the educational task (Table 1). At the same time, students studying in the field of training «Tourism» were in the first place $-33.3 \%$. The worst results $-0.0 \%$ - were shown by students studying in the direction of training "Applied Informatics». In General, such a low indicator is probably due to the fact that students do not have the habit of thinking about what goals a particular task is given to achieve. In addition, there are clearly shortcomings in the work of a General education school, which failed to instill in students the skills of meaningful academic work. 
Table 1: Self-determination of the purpose of the training task

\begin{tabular}{|l|c|c|c|c|c|c|c|c|}
\hline $\begin{array}{c}\text { Direction of } \\
\text { training }\end{array}$ & $\mathbf{1}$ & $\mathbf{2}$ & $\mathbf{3}$ & $\mathbf{4}$ & $\mathbf{5}$ & $\mathbf{6}$ & $\mathbf{7}$ & Total \\
\hline $\begin{array}{l}\text { Answered } \\
\text { correctly }\end{array}$ & 3 & 3 & 2 & 2 & 7 & 1 & 0 & 18 \\
\hline In \%\% & $25,0 \%$ & $21,4 \%$ & $10,0 \%$ & $18,2 \%$ & $33,3 \%$ & $11,1 \%$ & $0,0 \%$ & $18,6 \%$ \\
\hline $\begin{array}{l}\text { Answered } \\
\text { incorrectly }\end{array}$ & 9 & 11 & 18 & 9 & 14 & 8 & 10 & 79 \\
\hline In \%\% & $75,0 \%$ & $78,6 \%$ & $90,0 \%$ & $81,8 \%$ & $66,7 \%$ & $88,9 \%$ & $100,0 \%$ & $81,4 \%$ \\
\hline
\end{tabular}

Of the 18 students who gave the correct answer, 12 were more specific and said that the goal of the task was to learn how to make a table based on a sample. This marked the application aspect of the task. A broader understanding was demonstrated by 4 people who noted that the goal of the task is: «to Learn how to independently determine the source of information and organize information according to a sample». This understanding of the purpose of the task should be recognized as more correct, since the acquired skill is also applicable to other similar types of educational activities.

The second task was to identify the optimal sources of information on the Internet for compiling an information table. This task was completed by only 43 people or $44.3 \%$ of students. The best indicators in their group were demonstrated by students of the "Documentary Science» direction - 63.6\%, students of the "Tourism» direction were in second place, and the difference between the first and second places was only $1.7 \%$ (See: Table 2). The worst results of the work were shown by students of the «Land Management» direction - $11.1 \%$.

Table 2: Determining the optimal source of information

\begin{tabular}{|l|c|c|c|c|c|c|c|c|}
\hline \multicolumn{1}{|c|}{$\begin{array}{c}\text { Direction of } \\
\text { training }\end{array}$} & $\mathbf{1}$ & $\mathbf{2}$ & $\mathbf{3}$ & $\mathbf{4}$ & $\mathbf{5}$ & $\mathbf{6}$ & $\mathbf{7}$ & Total \\
\hline $\begin{array}{l}\text { Answered } \\
\text { correctly }\end{array}$ & 7 & 7 & 4 & 7 & 13 & 1 & 4 & 43 \\
\hline In \%\% & $58,3 \%$ & $50,0 \%$ & $20,0 \%$ & $63,6 \%$ & $61,9 \%$ & $11,1 \%$ & $40,0 \%$ & $44,3 \%$ \\
\hline $\begin{array}{l}\text { Answered } \\
\text { incorrectly }\end{array}$ & 5 & 7 & 16 & 4 & 8 & 8 & 6 & 54 \\
\hline In \%\% & $41,7 \%$ & $50,0 \%$ & $80,0 \%$ & $36,4 \%$ & $38,1 \%$ & $88,9 \%$ & $60,0 \%$ & $55,7 \%$ \\
\hline
\end{tabular}

Similar difficulties in the independent work of students are noted in other universities. Thus, the Krasnoyarsk scientists, who studied the formation of student information competencies, noted that their questionnaire: «... showed a lack, and in most cases a complete lack, of information skills and skills among students, «especially those related to...» with the application of knowledge and skills in the new conditions, with the preparation of tasks and self-control in the process of their solution» (Goncharova Ya. S. and etc., 2017, p. 77).

The third task concerned the ability to develop an algorithm of educational actions, in this case-an algorithm for searching and systematizing information based on the available sample (See: table 3). it was Assumed that students should develop the following algorithm: 1) understand the task; 2 ) study the parameters of the sample; 3 ) find the optimal source of information; 4) make an information table; 5) check the work performed; 6) send the work to the teacher. 
Table 3: Development of the task execution algorithm

\begin{tabular}{|l|c|c|c|c|c|c|c|c|}
\hline $\begin{array}{c}\text { Direction of } \\
\text { training }\end{array}$ & $\mathbf{1}$ & $\mathbf{2}$ & $\mathbf{3}$ & $\mathbf{4}$ & $\mathbf{5}$ & $\mathbf{6}$ & $\mathbf{7}$ & Total \\
\hline $\begin{array}{l}\text { Answered } \\
\text { correctly }\end{array}$ & 4 & 4 & 3 & 4 & 3 & 0 & 1 & 19 \\
\hline In \%\% & $33,3 \%$ & $28,6 \%$ & $15,0 \%$ & $36,4 \%$ & $14,3 \%$ & $0,0 \%$ & $10,0 \%$ & $19,6 \%$ \\
\hline $\begin{array}{l}\text { Answered } \\
\text { incorrectly }\end{array}$ & 8 & 10 & 17 & 7 & 18 & 9 & 9 & 78 \\
\hline In \%\% & $66,7 \%$ & $71,4 \%$ & $85,0 \%$ & $63,6 \%$ & $85,7 \%$ & $100,0 \%$ & $90,0 \%$ & $80,4 \%$ \\
\hline
\end{tabular}

This task was not much easier than the first task to determine the purpose of the work. Only $19.6 \%$ managed it. Students of the direction "Documentary Science» coped best with the work on algorithmization of the educational task $-36.4 \%$. None of the students of the direction «Land Management» did not cope with this task. Teachers face the problem of forming the ability to work according to algorithms even in classes in mathematics and computer science, where they simply cannot do without algorithmic competence (Sergeev A.M., 2017).

Even lower results were demonstrated when performing the applied part of the work - the second task drawing up the table. On the first attempt, only two people coped with the task: one student studying in the direction of «History» and one student studying in the direction of «Land Management». On the second attempt, 32 people coped with the task, on the third -30 , on the fourth-15, on the fifth-18. The organizers of the experiment agreed to consider three attempts to present a correctly completed work as an acceptable bar. The greatest success in overcoming the border barrier was demonstrated by the students of the direction of training «Documentary Science».

All $100 \%$ of the students completed the work within three attempts. In second place were the representatives of the direction «History» and $91.6 \%$; in the third, students of the specialty «Tourism» $-71,4 \%$; the fourth «Land Management» from 66.7\%; on the fifth - « Geography» with 64.3 per cent; on the sixth the students of the direction «Applied Informatics» - 50,0\%; the seventh - «Ecology» with 35,0\%, which is 2.9 times worse than the first position. On average, $66.0 \%$ of students completed the first three attempts. The worst results were demonstrated by students of the «Ecology» direction, of which $55.0 \%$ completed the work only on the fifth attempt.

\section{DISCUSSION}

At the end of the experiment and conducting an in-depth interview, the results were discussed with students. In the subsequent discussion of the results, 28 out of 79 people who did not complete the goal-setting task noted that they did not understand the task, 51 people explained their failure by saying that they had never completed such a task. Of the 36 students who did not complete the task to determine the optimal sources of information, 15 explained that they did not understand what «optimal source of information» means; 10 people relied on specialized, but not relevant resources; 11 people simply «did not answer the question». All 78 people who did not complete the task of developing an algorithm for performing a practical task, or who performed it incorrectly, later noted that they did not have experience working on the algorithm in the study of Humanities. Teachers of the Department of documentation studies of the University also took part in the discussion of the results of the experiment.

\section{CONCLUSIONS}

So, more than $80 \%$ of students were unable to set goals; more than half of students $(55.7 \%)$ could not determine the optimal source of information; $80.4 \%$ of students could not develop an algorithm for performing the work; only $66.0 \%$ of students completed the task in the first three attempts. This allows us to draw the following conclusions:

- The majority of students who participated in the experiment are unable to consciously perform educational work, work according to algorithms, which indicates shortcomings in the work of a General education school; 
- The majority of students took more than two attempts to pass the practical work, which indicates the inability to work by analogy, as well as the inattention of students;

- The University should conduct preparatory classes for first-year students in order to develop information and universal competencies.

\section{ACKNOWLEDGEMENTS}

The Authors thank the students who took part in the experiment and the teachers of the Department who agreed to discuss its results.

The widespread use of information technologies in education does not eliminate the need for purposeful and conscious learning activities. New social, socio-cultural conditions « ... require an adequate change in the content and methods of organizing the educational process. The Institute of education is an open complex nonlinear dynamic self-organized system, the purpose of which is to train specialists capable of creative activity and non-standard thinking in a dynamically developing social... environment» (Noskova T.N., 2016, p. 25). The use of modern gadgets does not free students from the need to understand educational processes. Taking into account these features of the modern educational process, both the work of the University and each teacher should be built.

\section{REFERENCE LIST}

1. Goncharova, Ya.S., Fedorchenko, I.S., Kustov A.V., Sergiyakova, Yu.T. (2017) Student's readiness for independent information search as a factor of successful education at the university // Innovative economy: prospects for development and improvement. 2017. № 1 (19). Pp. 75-78.

2. Grigoriev, A.V. (2019) Pedagogical competence: object, subject, purpose, tasks, functions // Science and Education: New time. 2019. № 1 (30). Pp. 469-472.

3. Korableva, E.V., Muzychenko, M.Ya. (2018) Informatization of education as a comprehensive strategy of the global world // Methodical questions of teaching of information and communication in higher education. 2018. Vol. 7. № 3. Pp. 27-29.

4. Koreneva, A.A. (2016) Experience of goal-setting formation in educational activities of university students // In the collection: Humanitarian education: history, traditions, prospects collection of scientific works. Elec, 2016. Pp. 27-35.

5. Lezhneva, E.A. (2016) Development of goal-setting skills in the process of forming the motivational basis of professional strategy of students-teachers-psychologists // New science: From idea to result. 2016. № 8-2 (96). Pp. 86-90.

6. Noskova, T.N., Pavlova, T.B., Yakovleva, O.V. (2016) Some effects of informatization of the educational environment of a modern university // Open Education. 2016.Vol. 20. № 3. Pp. 24-30.

7. Popova, V.V. (2016) Formation of algorithmic competence among students of professional educational organizations in the process of teaching mathematics // Bulletin of the Siberian Institute of Business and Information Technologies. 2016. № 2 (18). Pp. 138-142.

8. Sergeeva, A.M. (2017) Goal-setting Skills in students // Questions of pedagogy. 2017. № 10. Pp. 86-88. 